\title{
Science and Religion in Meta-Perspective - Part II
}

\author{
Herman J. Pietersen \\ Professor, University of Limpopo, Turfloop Campus 0727, Republic of South Africa \\ herman.pietersen@ul.ac.za
}

\section{Doi:10.5901/mjss.2014.v5n20p2151}

\section{Abstract}

\begin{abstract}
A meta-theory was developed that brought together implicit premises or world views that constantly re-surface in human thought. Although these elements, which are often referred to in the literature as the result of differences in human 'temperament', have long been part of the scholarly activity of humankind, a comprehensive synthesis has been lacking so far. In order to redress this shortcoming, an integrated perspective, supported by scholarly evidence, regarding basic characteristics of making sense of life and world is introduced. As a result four paradigmatic or root intellectual orientations (designated as type I, type II, type III and type IV) have been identified. The theory was found to be applicable across a wide range of thinkers, scholarly disciplines, and cultures. In the current paper (Part II) the theory is applied in terms of the objectivist-empyrean (type I) tendency in S-R, as represented by the ideas of the physicist lan Barbour, Philip Clayton (philosopher) and of Wentzel van Huyssteen (theologian). A second section focuses on the objectivist-empiricist (type II) inclination as manifested in the work of John Polkinghorne (physicist), Arthur Peacocke (bio-chemist), and Gregory Peterson (theologian).
\end{abstract}

Keywords: Barbour, Clayton, van Huyssteen, Polkinghorne, Peacocke, Peterson

\section{Introduction}

In this section the thought of a number of prominent S-R thinkers in the type I mode (Barbour, Clayton and van Huyssteen) are briefly reviewed in terms of the framework of archetypal orientations (see Figure 1).

It must be borne in mind that the S-R field is basically a multi-disciplinary endeavour, and it is therefore to be expected that there will be a variety of theoretical and methodological stances, and mutual borrowing of ideas and concepts from different areas. The S-R field is not, as such, science, or theology, or philosophy, but essentially a speculative venture straddling all three areas.

A common denominator is that participants, especially the scientists, share a belief in (or are at least admirers of) the 'scientific way,' in the type II modality of mind. The physicist, John Polkinghorne succinctly phrases this as the conviction that: 'epistemology (truth) models ontology (reality),' or, stated differently, that what we know (epistemology) indeed tells us - is a true account or reflection of - the way things really are (ontology), and not a 'social construction,' or 'truth as text.'

Figure 1: The type I and type II tendencies in S-R

\begin{tabular}{|l|l|}
\hline Type II & Type I \\
$>$ Polkinghorne & $>$ Barbour \\
$>$ Peacocke & $>$ Clayton \\
$>$ Peterson & $>$ Van Huyssteen \\
\hline Type III & Type IV \\
\hline
\end{tabular}

\section{The Objectivist-Empyrean tendency in S-R (Type I)}

\section{1 lan Barbour}

lan Barbour (a physicist and priest) is generally recognized as the leading figure in the modern S-R enterprise, and perhaps best known for his Religion in an Age of Science (1990), a magisterial survey and comparison of paradigms, models and methods in science and religion. His question (which is also at the heart of the S-R endeavour) is: "What view 
of God is consistent with the scientific understanding of the world?" (Barbour, 1990: xiii).

The basic challenge to religion is undoubtedly still the successes of modern science. Scientists themselves, though they are aware of and acknowledge the fallibility and open-endedness of the scientific endeavour, are guided by the regulating belief that science (and the methods of science) provides objective (empirically supported) truths about nature and the universe. There are many reliably confirmed truths in the natural and life sciences, which no amount of antiscience, anti-establishment critique and rhetoric (mostly under the umbrella-term: 'postmodernism') can explain away. The law of gravity holds everywhere - it's neither literary fiction, nor a colonialist ploy, for that matter.

In typical objectivist-empyrean fashion, Barbour starts with a basic framework of various types of relationship between science and religion, namely, independence, conflict, dialogue and integration. His aim is to pursue dialogue between and eventual integration of science and religion, and favours a top-down, hierarchical, multi-levelled systems view of the world, that, he believes, avoids the Cartesian duality of mind and body, spirit and matter. As far as divine action is concerned he prefers process theology as answer.

Barbour emphasises the importance of philosophy for the S-R field: "especially epistemology and metaphysics" (Barbour, 1990: 3), thus showing his empyrean orientation. Though he acknowledges the position of independence of science and religion as a first approximation, his thought (in line with the ideological thrust of the Zygon movement discussed in Part I) is mainly directed toward its integration. He proposes a 'systematic synthesis' in which: "...both science and religion contribute to the development of an inclusive metaphysics, such as that of process philosophy" (Barbour, 1990: 23), though he also cautions against uncritical use of the latter.

According to Barbour, both science and religion are characterized by similar cognitive components, namely: paradigms, theories, models and data. Figure 2 presents his comparison of the structures of scientific and religious thought. He presents the same criteria for assessing theories in both domains, namely: agreement with data, coherence, scope, and fertility.

Figure 2: Barbour's top-down structures of science and religion (Barbour, 1990: 30 - 38)

\begin{tabular}{|l|l|}
\hline Science & Religion \\
\hline Imagination/analogies/models & Imagination/analogies/models \\
\hline Concepts/theories & Concepts/beliefs/doctrine \\
\hline Theories influence observation & Beliefs/doctrine influence experience and interpretation \\
\hline Observation/data & Religious experience/ story/ritual \\
\hline
\end{tabular}

He follows a philosophy of 'critical realism' which holds that existence or being precedes theorizing. In this process, models are important for both science and religion, though in the religious sphere models also serve the purpose of 'personal transformation and reorientation,' which is not the case in science: "Models, [which forms the basis of theories]...are to be taken seriously but not literally; they are neither literal pictures [Classical realism] nor useful fictions [Instrumentalism] but limited and inadequate ways of imagining what is not observable." (Barbour, 1990: 43).

Figures 3 and 4 present a sketch of parallels between scientific and religious paradigms, and a summary of his discussion of changing views of nature, respectively. It is interesting to note (see Figure 3 ) the bias that creeps into Barbour's comparison of these paradigms. Although he is at pains to identify similarities (reflecting the largely ecumenical stance of his writing), science still comes out on top and is positively portrayed as being more flexible and open to new ideas and findings; whilst dogma seems to be the rule in religion.

Figure 3: Barbour's parallels between the nature of paradigms in science and religion (Barbour, 1990: 43 - 45)

\begin{tabular}{|l|l|}
\hline \multicolumn{1}{|c|}{ Science } & \multicolumn{1}{c|}{ Religion } \\
\hline $\begin{array}{l}\text { 1. All data are paradigm-dependent, but there are data on which } \\
\text { adherents of rival paradigms can agree. }\end{array}$ & 1. Religious experience is paradigm-dependent. \\
\hline $\begin{array}{l}\text { 2. Paradigms are resistant to falsification by data, but data do } \\
\text { cumulatively affect the acceptability of a paradigm. }\end{array}$ & $\begin{array}{l}\text { 2. Religious paradigms are highly resistant to } \\
\text { falsification. }\end{array}$ \\
\hline $\begin{array}{l}\text { 3. There are no rules for paradigm choice, but there are shared criteria } \\
\text { for judgment in evaluating paradigms. }\end{array}$ & 3. There are no rules for paradigm choice in religion. \\
\hline
\end{tabular}


Figure 4: Barbour's comparison of changing views of nature (Barbour, 1990: 189 - 221)

\begin{tabular}{|l|l|l|}
\hline Medieval & Newtonian & Twentieth Century \\
\hline 1. Fixed order & Change as rearrangement & Evolutionary, historical, emergent \\
\hline 2. Teleological & Deterministic & Law and chance, structure and openness \\
\hline 3. Substantive & Atomistic & Relational, ecological, interdependent \\
\hline 4. Hierarchical, anthropocentric & Reductionistic & Systems and wholes, organismic \\
\hline 5. Dualistic (spirit/matter) & Dualistic (mind/body) & Multi-levelled \\
\hline 6. Kingdom & Machine & Community \\
\hline
\end{tabular}

He also discusses the relevance of process philosophy, and presents a variation of the Cartesian split when he observes that process thought: "...takes mental and neural phenomena to be two aspects of the same events." (Barbour, 1990: 225). Figure 5 summarises his wide-ranging discussion of different models or ways of conceiving God's role in the world. (Barbour, 1990: 244 - 261).

Figure 5: Barbour's survey of models of God's role in nature

\begin{tabular}{|l|l|l|}
\hline Theology type & Dominant model & Conceptual elaboration \\
\hline Classical & Rule-Kingdom & Omnipotent, omniscient, unchanging sovereign \\
\hline Deist & Clockmaker-Clock & Designer of a law-abiding world \\
\hline Neo-Thomist & Workman-Tool & Primary cause working through secondary causes \\
\hline Kenotic & Parent-Child & Voluntary self-limitation and vulnerability \\
\hline Existentialist & None & God acts only in personal life \\
\hline Linguistic & Agent-Action & Events in the world as God's action \\
\hline Embodiment & Person-Body & The world as God's body \\
\hline Process & Leader-Community & Creative participant in the cosmic community \\
\hline
\end{tabular}

Barbour's groundbreaking contribution to the S-R field is widely acknowledged and highly appreciated. But, of course, there is also the inevitable criticism that follows in the wake of any intellectual product that is put in the marketplace of ideas. Some issues and concerns about his thought are briefly indicated below:

> His four-fold framework, nested in the conflict-thesis, is too one-sided, analytically unhelpful and ideological in its basic thrust (Cantor \& Kenney, 2001: 765);

$>$ His approach is too cognitive in content and does not sufficiently address religious aspects: "... it omits the crucial role of faith, salvation, and the revelation of such fundamental doctrines as the Trinity." (Cantor \& Kenney, 2001: 777);

$>$ He does not address the question of: "How is it possible to conceive of a personal God-specifically, the God in whom Christians confess belief-creating and active within the universe revealed by the natural sciences?" (Crain, 1997: 426);

$>$ There is little if any discussion concerning: "...the relationship between various world theologies and the natural sciences." (Crain, 1997: 432);

$>$ Barbour's work: "...echoes the logical positivist vision of unification and has a strong bias toward science as the sole source of rationality, which does not take theology fully seriously." (Smedes, 2008: 235);

$>$ Barbour (as with the S-R field in general) does not address the basic question: "Why do we need an interaction between science and religion?" (Smedes, 2008: 255).

\subsection{Philip Clayton}

Philip Clayton holds doctorates in both philosophy and in religious studies, and is a prominent second-generation S-R scholar. Given his background, he by and large takes a philosophical (philosophy of mind, philosophy of science) approach to the science and religion relationship, with a focus on topics such as rationality models, models of emergence, and the Lakatosian framework of 'research programs' for discussing the God/world relationship. Within the context of the meta-theory utilized in the present work, this places him in the objectivist-empyrean category.

In Explanation from physics to theology: An essay in rationality and religion, (1989) he explores the nature of justification and explanation in science and religion, stating that: "With the aid of the work of Imre Lakatos, I steer a middle course between purely formal and purely contextual treatments of rationality." (Clayton, 1989: vii). His thesis is 
that there is continuum of 'epistemic positions that lies: ".... between absolute, universal, or objective justification claims and purely private justifications." (Clayton, 1989: 2). Thus, it would seem, he attempts to accommodate both objectivist and subjectivist modes of thought. He also wishes to make room for the 'intersubjective approach' to rationality.

He sees his main task in the above-mentioned work, as going beyond the private and 'communal explanations' of religion, and proposes a transcommunal, 'pansubjectivist' (thus, empyrean) approach: "... since these explanations often claim validity for (virtually) all knowing subjects." (Clayton, 1989: 5).

In Clayton's view, the philosophy of science of Imre Lakatos (which he, Clayton, interprets as postfoundationalism) has: "...effectively overcome the traditional dichotomy between rationalism and fideism in the faith/reason debate, thus requiring a complete rethinking of what a natural theology would entail." (Clayton, 1989: 6).

Although he seems to subscribe to what one may describe as a 'pluralistic rationality,' and do not wish to provide a list of rationality standards, he nevertheless follows the objectivist impulse to state a number of epistemological criteria or rationality conditions for religion.

His criteria are: external reference (indicating his preference for ontological realism); truth as referring to the epistemology of justified true belief or: "... what is in fact the case..." (Clayton, 1989: 7), thus going beyond individual or collective religious experience; validity, which, according to Clayton is not a return to objectivism, yet requires a 'certain burden of proof' from believers, that goes beyond claims of intersubjective validity; rationality, which, for him, means that: "...that theology cannot avoid an appeal to broader canons of rational argumentation and explanatory adequacy." (Clayton, 1989: 13).

He specifies the following criteria for theology to become a science (Clayton, 1989: 161 and 162):

- It must be open to intersubjective examination and criticism;

- In principle no limits can be set as to who should participate;

- No solution should be based on 'privileged premises';

- All beliefs should be treated as hypotheses that are: "...internally coherent and clearly criticizable"

Ten years later, in God and contemporary science, (1997) he asks the empyrean question: "...what general framework for conceiving of the God/world relation is adequate both to the biblical data and to the contemporary philosophical and scientific context?" (Clayton, 1997: 83). His answer is that: "...panentheism dissolves the dichotomy that structured so many of the theological debates on this topic." (Clayton, 1997: 88). For Clayton panentheism avoids reduction to the world of creatures and of matter: "God was before the world and will exist after it." (Clayton, 1997: 94). Figure 6 presents Clayton's arguments for panentheism. (Clayton, 1997: 96 - 100).

Figure 6: Clayton's case for panentheism

\begin{tabular}{|l|}
\hline 1. The inadequacy of atheism \\
\hline 2. The inconsistency of classical Western theism \\
\hline 3. The biblical resistance to dualism \\
\hline 4. Divine infinity (which logically encompasses the finite world) \\
\hline 5. The problem of divine causality (the action of God is analogous to the body's relationship to the mind or soul) \\
\hline 6. A closer relationship with God \\
\hline
\end{tabular}

Clayton, like many other scholars, also finds himself confronted with the antinomy of the personal and the impersonal, wishing to accommodate both, yet favoring the latter (objectivist) option, stating: "Still, one must be careful not to attribute personal attributes to the one all-that-is which are denied by the pantheistic position itself." (Clayton, 1997: 117). In addition to his panentheism Clayton is also a leading voice for the so-called emergentist approach, which attempts to explain God's action in the world other than through a Cartesian mind/body dualism.

For Clayton, emergence is the: "...theory that cosmic evolution repeatedly includes unpredictable, irreducible, and novel appearances." (Clayton, 2004: 39). His purpose is to establish a theoretical framework (Clayton, 2004: 40 - 44) for discussing the concept of emergence, identifying five different meanings of emergence, namely, (a) $E_{1}$ : theories of emergence within specific scientific fields; (b) $E_{2}$ : levels of emergence within the natural world; (c) $E_{3}$ : patterns across scientific theories; (d) E4: a theory about the patterns in the transitions between sciences; and (e) E5: the metaphysics of emergence.

Figure 7 presents Clayton's scheme for representing the characteristics of the theory of 'strong emergence' (a topdown approach that postulates the causal impact of higher levels on lower levels in the world). 
Figure 7: Clayton's theoretical structure of strong emergence (Clayton, 2004: 59 - 62)

\begin{tabular}{|l|l|}
\hline Characteristic & Description \\
\hline (1) Monism & There is one natural world \\
\hline (2) Hierarchical complexity & This world appears to be hierarchically structured \\
\hline (3) Temporal or emergentist monism & $\begin{array}{l}\text { This hierarchical structuring takes place over time: Darwinian evolution move from the } \\
\text { simple to the more complex }\end{array}$ \\
\hline (4) No monolithic law of emergence & $\begin{array}{l}\text { The details of the process of emergence - the manner of the emergence of one level from } \\
\text { another, the qualities of the emergent level, the degree to which the 'lower' controls the } \\
\text { 'higher', etc. - vary greatly }\end{array}$ \\
\hline (5) Patterns across levels of emergence & $\begin{array}{l}\text { There are certain broad similarities shared in common by most of the various instances of } \\
\text { emergence in natural history }\end{array}$ \\
\hline (6) Downward causation & $\begin{array}{l}\text { In some cases, phenomena at } \mathrm{L}_{2} \text { exercise a causal effect on } \mathrm{L}_{1} \text { which is not reducible to } \\
\text { an } \mathrm{L}_{1} \text { causal history }\end{array}$ \\
\hline (7) Emergentist pluralism & $\begin{array}{l}\text { Downward causation does mean that the position is 'pluralist', in so far as it asserts that } \\
\text { really distinct levels occur within the one natural world }\end{array}$ \\
\hline (8) 'Mind' as emergent & Both upward and downward influences are operative \\
\hline
\end{tabular}

Finally, some critical comments on Clayton's ideas are as follows:

- He uses: "...the relationship between mind and brain as analogy for the relationship between God and the world [but] this runs the risk of understanding God as analogous to the mind and hence secondary and emergent relative to the world." (Drees, 1999: 515);

- He: "...concentrates on cognitive claims rather than on religions as complex practices." (Drees, 1999: 516);

- Clayton's thesis becomes an exercise in trying to make the way God acts in the world commensurate with human conceptual capacity (Puddefoot, 2000: 228).

\subsection{Wentzel van Huyssteen}

J. Wentzel van Huyssteen is a theologian with a background also in philosophy. Utilizing ideas and concepts from philosophy of science, his empyrean venture aims to explore the possibility of a broad approach to rationality, one that will provide a truth perspective encompassing both scientific and theological reasoning. The motive behind his work is to achieve a position of intellectual credibility (equal scholarly status) for theology in a science-dominated world.

Already in his early work, Theology and the justification of faith: Constructing theories in systematic theology (1989), and relying on both philosophy of science theories and more science-inclined theologies such as those of Pannenberg, van Huyssteen became: "...convinced that no rationality model in modern philosophy of science can finally and conclusively define the term rationality. (van Huyssteen, 1989: 190).

The issues of rationality, objectivity and truth are of central interest to him. He also expresses his support for critical realism, an approach common to most S-R participants. Setting the tone for his later work, van Huyssteen decided to adopt an approach to rationality that: "...has a historico-sociological character but is not exhausted by this contextuality, because certain criteria of rationality are also inter-contextually or inter-paradigmatically valid. " (van Huyssteen, 1989: $\mathrm{xv})$.

Ten years later he delivered his matured thought with: The shaping of rationality: toward interdisciplinarity in theology and science (1999). In this work he offers a model of rationality for theology that respects both the rationality of science and the more contextualized rationality of 'interdisciplinary reflection,' stating that: "In the wake of the postmodern challenge to rationality we will therefore be pursuing the possibility that shared rationality may actually be identified for the sciences, for theology, and for other forms of inquiry." (van Huyssteen, 1999: 3).

This alternative he refers to as 'postfoundationalist rationality,' a model of rationality that: "... will take seriously the challenge of much of postmodern thinking, but will carefully distinguish between constructive and deconstructive modes of postmodern thinking." (van Huyssteen, 1999: 8). Although he is at pains to avoid any suggestion of a 'totalizing metanarrative,' his empyrean meta-theoretical inclination shows in his emphasis on: "...the need for a more comprehensive and integrative approach to the problem of human knowledge." (van Huyssteen, 1999: 4). For van Huyssteen this essentially means: "...splitting the difference between modernity and postmodernity..." (van Huyssteen, 1999: 174).

He goes on to describe various elements and facets that are important in the shaping of rationality as an intersubjective and 'fallibilist process of progressive problem-solving,' a 'commonsense reasonableness' (van Huyssteen, 1999: 12), that utilizes the 'rich resources of rationality' (a favorite expression). Figure 8 shows some of the elements and 
characteristics that van Huyssteen includes in his broad conception of rationality; a rationality in which: "Scientific knowing will thus turn out to differ from other forms of human knowing, and therefore from theological knowing, only in degree and emphasis." (van Huyssteen, 1999: 13).

In sum: van Huyssteen identifies various human characteristics that play a part in and form the constituent components or 'rich resources' of his postfoundationalist rationality.

Some critical comments on van Huyssteen's ideas are as follows:

> The question may be asked: what are the reasoning procedures and criteria (rules), involved in this beyonddisciplinary ('transversal') discourse and decision-making, apart from being a 'space' where problem-solving minds, using 'common-sense' reasoning, meet to hopefully agree on what is to be regarded as truth or knowledge?

Figure 8: Some elements of van Huyssteen's 'rich resources' model of rationality

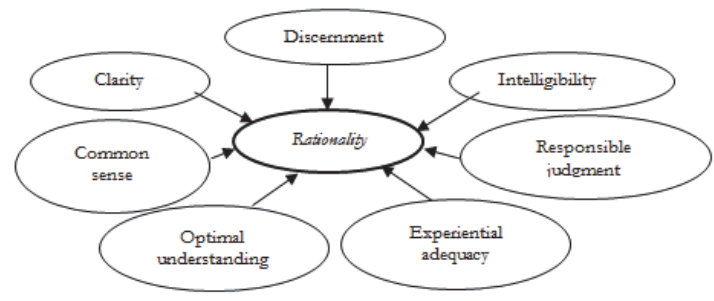

Dith reference to his proposal of cross-contextual and interdisciplinary conversation, it is remarked that: "...the demonstration of their actual possibility is not, however, as clear as one might hope for." (Murray, 2000: 216);

$>$ "He has made a claim for a theistic outlook as the best explanation, but has never argued the case for this claim." (Stone, 2000: 424);

$>$ There is not much: "...about the conflict of interpretations and the criteria by which such conflicts are to be settled." (Brown, 2001: 95);

> It is: "...surprising to find so little mention of God..." (Peterson, 2008: 470); 50

> "Like most impressionistic pictures...this one is best viewed from a distance. Those who look closely for detailed, even mundane connections, will be disappointed by the sweeping generalities and swift associations..." (Schoen, 2009: 51).

\section{The Objectivist-Empiricist Tendency in S-R (Type II)}

\subsection{John Polkinghorne}

John Polkinghorne is a theoretical physicist who made a mid-career change to become an Anglican priest. Together with lan Barbour and Arthur Peacocke he is one of the three leading first-generation science and religion thinkers and writers in the post WWII context.

In an objectivist-empiricist (type II) fashion, his venture is primarily one of drawing parallels between natural science (mostly physics) and religion (Christianity), in an effort to seek consonance between them. An important personal motive for Polkinghorne is that: "...my experience as a physicist and my experience as a priest have to be capable of being held together, without compartmentalism or dishonest adjustment." (Polkinghorne, 1988: 69). Here is another example of the drive in the S-R field, to seek some unifying pattern (similar to the search in physics for a grand unified theory, or GUT).

An Aristotelian (what he refers to as a "bottom-up) approach is characteristic of his work in the S-R field, and is expressed in the meta-theoretically revealing metaphor that he prefers: "A hut on the ground rather than a castle in the sky." (Polkinghorne, 1988: 83). Though he appreciates the role of philosophy in the S-R discussion, he is not, contra Barbour for instance, keen on developing a metaphysical (empyrean) theory or framework. This is clearly reflected in his aversion to building a 'castle in the sky.' He starts from the world of science and then seeks 'connections' with religion (specifically, the Christian religion).

In one of his earlier works, Science and creation: the search for understanding (1988), he sets out some of his views on the science and religion relationship, briefly sampled as follows: 
$>$ The 'arena of their interaction,' is natural theology (to be distinguished from a 'theology of nature'), which, in the type II modality of mind, he describes as: "...the search for the knowledge of God by the exercise of reason [objectivist] and the inspection of the world [empiricist]." (Polkinghorne, 1988: 2);

$>$ The aim should be: "......to construct a natural theology in true accord with the way things are," one of his favorite expressions that also reflect his ontological realism as scientist. (Polkinghorne, 1988: 6);

$>\mathrm{He}$ is convinced that the 'Rationality of the Creator' is the source of the: "...deep-seated congruence of the rationality present in our minds with the rationality present in the world." (Polkinghorne, 1988: 22);

$>$ The S-R dialogue can be mutually beneficial, with the proviso that: "Religion, if it is to take seriously its claim that the world is the creation of God, must be humble enough to learn from science what that world is actually like." (Polkinghorne, 1988: 98);

$>$ God can only will what is in accord with his character, thus: "The rational God must respect reason." (Polkinghorne, 1988: 51);

> Although the personal (anthropological) God is not denied, it is important to realize that: "...God's love for the world in creation, though including humanity, is not exclusively man-centred." (Polkinghorne, 1988: 52);

> Panentheism is rejected because it does not accept God's true sovereignty and 'otherness.' (Polkinghorne, 1988: 53);

$>$ With regard to resurrection, there is the: "...hope of a destiny beyond death in which the information-bearing pattern (which is the persisting element of ourselves continuing through the ceaseless changes in the matter making up our bodies) will be recreated in an unimaginable new environment of God's choosing." (Polkinghorne, 1988: 65);

> Miracles must be understood as: "...as a sign of a deeper rationality underlying the whole, rather than as a divine tour de force bearing an arbitrary relation to the rest of the world's process." (Polkinghorne, 1988: 80);

$>$ Following his motto of 'epistemology models ontology,' he refuses: "...to join the idealists in assigning an ontological priority to the mental over the material." (Polkinghorne, 1988: 71);

$>$ He discards the Cartesian duality of mind and matter, stating that: "...all I can set is the humble picture of material/mental complementarity by which the physical world participates in a wider noetic world, all being held in being by the creative will of God." (Polkinghorne, 1988: 83).

In a later work Serious talk: science and religion in dialogue, (1995) he provides a series of parallels between science and religion. This work is conveniently summarized in Figures 9 to 17.

Figure 9: Polkinghorne's basic parallels between science and theology

\begin{tabular}{|c|c|}
\hline SCIENCE & THEOLOGY \\
\hline 1. Concerned with the rational exploration of what is. & 1. Concerned with the rational exploration of what is. \\
\hline 2. The physical world is rationally transparent. & 2. The physical world testifies to the Logos. \\
\hline $\begin{array}{l}\text { 3. The history of the universe depends upon fine-tuning in its } \\
\text { physical laws and circumstance. }\end{array}$ & 3. The world is a creation endowed with freedom. \\
\hline 4. The physical world is endowed with becoming. & 4. The world allows for God's providential action. \\
\hline 5. The physical world is often surprising. & 5. Theology challenges commonsense assumptions. \\
\hline 6. The investigation of the physical world is exciting. & 6. The insights of theology are exciting. \\
\hline 7. Science is problematic. & 7. Theology is problematic. \\
\hline
\end{tabular}

Figure 10: Polkinghorne's first parallel

\begin{tabular}{|c|c|}
\hline SCIENCE & THEOLOGY \\
\hline Science is concerned with the rational exploration of what is the case. & $\begin{array}{l}\text { Theology is concerned with the rational exploration of what } \\
\text { is the case. }\end{array}$ \\
\hline $\begin{array}{l}\text { 1. Theory and experiment are intertwined (critical realism) } \\
\text { 2. Science is about the impersonal ("it") } \\
\text { 3. All significant scientific facts are theory laden. } \\
\text { 4. Scientists wear "spectacles behind the eyes"; they have to "believe } \\
\text { in order to understand." } \\
\text { 5. Science depends on tacit skills (intuitive). }\end{array}$ & $\begin{array}{l}\text { 1. Church (and theology) employs critical reason. } \\
\text { 2. Theology is about the personal ("thou"). } \\
\text { 3. Theological beliefs are 'theory laden' (scripture) } \\
\text { 4. Theology wears "spectacles behind the eyes." (fides } \\
\text { quaerens intellectum) } \\
\text { 5. Faith involves commitment, not blind belief. }\end{array}$ \\
\hline
\end{tabular}


Figure 11: Polkinghorne's second parallel

\begin{tabular}{|l|}
\hline SCIENCE \\
\hline The physical world is rationally transparent. \\
\hline 1. The reason within (mathematics) and the \\
reason without (physics) match perfectly. \\
2. Universe's intelligibility signifies transcendence - \\
there is more than has met the scientific eye. \\
\hline
\end{tabular}

\section{THEOLOGY}

The physical world testifies to the Logos.

1. The "unreasonable effectiveness" of mathematics reveals the 'Mind of God' in the world.

2. The reason human minds so perfectly fits the rational structure of the world, lies in a deeper rationality - the rational will of the Creator.

Figure 12: Polkinghorne's third parallel

\section{SCIENCE}

The history of the universe depends upon fine-tuning in its physical laws and circumstance.

1. A fruitful world - a world capable of evolving anthropoi - is a very special universe (the anthropic principle).

2. An evolving universe involves chance and necessity.

\begin{tabular}{l} 
THEOLOGY \\
\hline The world is a creation endowed with freedom. \\
$\begin{array}{l}\text { 1. The fine-tuning (anthropic principle) of the physical world is given to the } \\
\text { universe by a Creator who wills it to be capable of a fruitful history. } \\
\text { 2. An evolutionary universe is allowed to realize its God-given potential. } \\
\text { (God is neither a 'cosmic tyrant', nor a 'deistic spectator'). }\end{array}$ \\
\hline
\end{tabular}

Figure 13: Polkinghorne's fourth parallel

\section{SCIENCE \\ The physical world is endowed with becoming.}

1. The open possibilities of a world of becoming have the character of "active information" and represent a top-down causality operating within wholes, which complements the bottom-up energetic causality of parts (which is what physics describes).

\begin{tabular}{l} 
THEOLOGY \\
\hline The world allows for God's providential action. \\
\hline $\begin{array}{l}\text { 1. God's hidden hand is working within a physical process } \\
\text { that is open and unpredictable; God's providence is } \\
\text { conceived as acting within the processes of nature, not } \\
\text { against it. }\end{array}$ \\
\hline
\end{tabular}

Figure 14: Polkinghorne's fifth parallel

\section{SCIENCE}

The physical world is often surprising.

1. Classical logic is true-false (either-or) logic, whereas quantum theory allows probabilistic adding together of possibilities beyond common sense.

\begin{tabular}{l} 
THEOLOGY \\
\hline Theology challenges commonsense assumptions. \\
\hline $\begin{array}{l}\text { 1. The infinity of God and the finiteness of human nature which is } \\
\text { focused on a single figure is a perplexing paradox that needs to be } \\
\text { engaged with. }\end{array}$ \\
\hline
\end{tabular}

Figure 15: Polkinghorne's sixth parallel

\section{SCIENCE}

The investigation of the physical world is exciting.

1. There is grandeur in the pattern and structure of the physical world that is deeply exciting to discover and satisfying to contemplate.

\begin{tabular}{|l|}
\hline THEOLOGY \\
\hline The insights of theology are exciting. \\
\hline $\begin{array}{l}\text { 1. That the ineffable God who is beyond human power to grasp should } \\
\text { have made himself known by living the life of a human being (Jesus } \\
\text { Christ) is 'deeply exciting'. }\end{array}$ \\
\hline
\end{tabular}

Figure 16: Polkinghorne's seventh parallel

\section{SCIENCE}

Science is problematic.

1. Quantum theory is used to great empirical effect, but still not properly understood.

2. The problem of reconciling general relativity and quantum theory.

THEOLOGY

Theology is problematic.

1. The problem of evil and suffering.

2. The problem of religious diversity. 
Figure 17: Polkinghorne's eighth parallel

\section{SCIENCE}

Science has things to say to theology.

1. The discoveries of physics will impose constraints upon of theological discourse.

2. The theologian must consider the scientific certainty that humanity will only be a fleeting episode in the history of the universe.

\section{THEOLOGY}

Theology has things to say to science.

1. The impersonal approach of science 'will never touch more than the periphery of human experience.'

2. Science does not address the questions of human significance, hope of life after death; the purpose of the universe (the 'why' questions).

In Beyond science: the wider human context, (1996) Polkinghorne addresses broader issues that affect the S-R field, such as the knowledge as social construction approach (coming mostly from the sociology of knowledge and postmodern quarters). His answer, simply stated, is that: "Science is socially influenced but it is not socially constructed." (Polkinghorne, 1996: 11).

In his The faith of a physicist, (1996a) Polkinghorne reiterates his (anti-Cartesian) preference for what he refers to as a 'dual-aspect monism,' which he explains as follows: "There is only one stuff in the world (not two - the material and the mental), but it can occur in two contrasting states (material and mental phases, a physicist would say) which explain our perception of the difference between mind and matter." (Polkinghorne, 1996a: 21).

He acknowledges the "...importance of the poets and artists" (Polkinghorne, 1996a: 40), to which theology may turn to express its symbolic truths. However, against the type III modality of mind, he also firmly states that: "expressivist views take too existential, psych-centred, a view of religious belief. Natural theology (understood as the search for God through reason and general experience) is an antidote..." (Polkinghorne, 1996a: 42).

Finally, some criticisms of Polkinghorne's approach are as follows:

$>$ His work: "... does not easily engage ethical, political, and cultural landscapes where the concrete contexts of particular people's lives engage their faith." (Pederson \& Trost, 2000: 977);

$>$ He has: "...not seriously taken into account the postmodern critiques including discussions of how language functions and of the power of metaphor." (Pederson \& Trost, 2000: 980);

$>$ His idea of God is 'God as Mind."' (Pederson \& Trost, 2000: 982).

\subsection{Arthur Peacocke}

Arthur Peacocke discusses various similarities (as well as dissimilarities) between science and religion, but is much more adamant that religion/theology must be brought into the scientific fold.

Peacocke is a biochemist and priest, who, already in his early work, Science and the Christian experiment, (1971) stated his desire for a synthesis of science and theology. However, for him (as for many S-R participants), this must be achieved in a way that is consistent with the methodology of science and the scientific understanding of the world: "...in both, the grounds and evidence for hypotheses and beliefs summarized in apparently propositional terms must be sought..." (Peacocke, 1971: 5).

His work and approach to S-R is characteristic of the type II (objectivist-empiricist) or scientific modality of mind, though he also substantially involves himself in the advocacy (type IV) mode. At times he 'demands' that theology become more like science (see Part III). Peacocke also does not shy away from being a strong critic of conventional religion/theology: "...the scientific vista for the twenty-first century constitutes a stimulus to theology to become more encompassing and inclusive...To some this might appear an iconoclastic program." (Peacocke, 1999: 697).

Throughout his writing he emphasizes both the impersonal and personal dimensions of understanding God and world, yet finds it difficult (as would be expected in terms of the meta-theoretical approach followed in the present work, and his own bias toward science) to reconcile them.

He strives hard to accommodate the impersonal-personal antimony. He speaks of both 'abstraction' and 'personal involvement,' and states that: "... both the scientific and theological enterprises are personal activities in the context of a community and...this personal dimension is a necessary element in the attainment of their ends." (Peacocke, 1971: 17). He even admits the importance of poetry (Dante seems to be his favourite), and re-emphasizes the personal dimension when he states that: "... The cosmos depends for its being on God who is at least personal and has created personalness in man out of non-personal materiality." (Peacocke, 1971: 199).

Like others S-R field, such as Barbour and Polkinghorne, he desires unity and proposes the 'sacramental universe' as unifying concept, stating that: "...even on a Christian basis, men must centre their hope on this world ...Any end to be 
achieved in a sacramental universe must be in and through the medium of the world we are actually in." (Peacocke, 1971: 197).

Thirty years later he opts for panentheism and a 'theology of evolution,' though still retaining the idea of a 'sacramental' universe. (Peacocke, 1999: 695). For Peacocke: "Such a revitalized theology allows one to conceive of humanity and Jesus the Christ in a fully evolutionary perspective without loss of an emphasis on the particularity of the Incarnation." (Peacocke, 1999: 695). He emphasizes the fact that humans are part of an evolving cosmos: "...we are stardust become persons" (Peacocke, 1999: 698); "...rising beasts rather than fallen angels..." (Peacocke, 1999: 701), expressing the wish that: "Surely we now have to escape from our anthropocentric myopia..." (Peacocke, 1999: 700).

He takes a dynamic systems view of the world, a world that consists of: "...webs of interconnection in which the state of the whole system influences the behavior of its parts." (Peacocke, 1999: 706). His thesis is that of: "whole-part influence as a clue to the understanding of God's interaction with the world (and possibly also to understanding personal agency and the mind-body problem)." (Peacocke, 1999: 706). Thus, God creates 'in and through the processes of the natural order,' which is not God himself (the pantheistic view), but only his action as Creator. (Peacocke, 1999: 707). Peacocke's choice of panentheism leads him to the view that: "...the world is to God rather as our bodies are to us as personal agents..."(Peacocke, 1999: 708). According to this scheme Jesus the Christ is seen as representing: "...the consummation of the evolutionary creative process..." (Peacocke, 1999: 710).

Peacocke is a critical realist with respect to both science and theology and against what he refers to as the: "...corruption... of postmodernist relativities." (Peacocke, 2002: 8). He supports the methodology of Inference to the Best Explanation (IBE) for both ventures, preferring the criteria of: comprehensiveness; fruitfulness; general cogency and plausibility; internal coherence and consistency; and, simplicity or elegance. (Peacocke, 2002: 28).

He uses the concept of an 'Ultimate Reality' to refer to the Creator who must be: "...supremely and unsurpassedly rational." (Peacocke, 2002: 41). This 'Ultimate Reality' must be: "...the self-existent Ground of Being; one, but a diversityin-unity, a Being of unfathomable richness; supremely and unsurpassedly rational; omniscient; omnipotent; omnipresent and eternal; and at least personal or supra-personal." (Peacocke, 2002: 43).

Peacocke wishes to preserve human freedom and agency in the world: "We are then seen not to be the mere playthings of God, but as sharing as co-creating creatures..." (Peacocke, 2002: 86). This term fits Peacocke's naturalism, in that the main component or stem of his expression refers to humans as 'creatures' By contrast (see Part III), in Hefner's 'created co-creator,' with its stronger personalistic emphasis, humans are depicted more optimistically and autonomously as 'co-creators.' Here is another instance of the contrast between types II (Peacocke) and III (Hefner) modalities of mind.

Figure 18 provides a summary of Peacocke's ideas on God as 'Ultimate Reality.'

Figure 18: Peacocke's God the 'Ultimate Reality' (Peacocke, 2002: 129 - 130)

1. Is the self-existent Ground of Being, giving existence to and sustaining in existence all-that-is

2. Is One - but a diversity-in-unity, a Being of unfathomable richness

3. Includes and penetrates all-that-is, but whose Being is more than and is not exhausted by it (panentheism)

4. Is supremely and unsurpassedly rational

5. Is the immanent Creator creating continuously in and through the processes of the natural order

6. Is omniscient, with only a probabilistic knowledge of the outcomes of some events

7. Is omnipotent, but self-limited by God's nature as Love

8. Gives existence to each segment of time for all-that-is-becoming

9. Is omnipresent to all past and present events and will be to all future ones

10. Is eternal, exists at all times - past, present and future

11. Transcends past and present created time (but does not know the future, which does not exist to know)

12. Possesses a dipolarity in relation to time, transcendent but also experiencing succession in relation to events and persons; hence is not 'timeless'; and is temporally, and so personally, related to humanity

13. Is (at least) personal or supra-personal - yet also has impersonal features

14. Is the ultimate ground and source of both law ('necessity') and 'chance' - an Improvisor of unsurpassed ingenuity

15. Has something akin to 'joy' and 'delight' in creation

16. Suffers in the creative processes of the world

17. Took a risk in creation

18. Is an Agent who affects holistically the state of the world-System and thereby, mediated by whole-part influences, can affect particular patterns of events to express divine intentions

19. Communicates with human persons through the constituents of the world by imparting meaning and significance to particular patterns of events 
$>$ It would seem that: "...cognitive science provides us with no models or metaphors for the theological task of understanding God..." (Bielfeldt, 2004: 601);

$>$ The information processing model is: "...inappropriate for understanding the divine mind." (Bielfeldt, 2004: 601).

\section{Summary}

The first section of the paper reviewed the work of three prominent S-R figures, all concerned with broader, more encompassing perspectives, in the empyrean (type I) intellectual tradition.

Barbour seeks an integrative, metaphysically informed platform for the S-R field, and ends up choosing Whiteheadian process thought. Clayton (a philosopher) also aims at a more encompassing view, and proposes panentheism. Van Huyssteen attempts to 'split the difference' between modernism and postmodernism, and proposes a 'transversal,' postfoundationalist rationality, in which the difference between scientific and theological reasoning becomes a matter of degree, not a dualism. The discussion also shows clear differences in their approaches, which should perhaps not be surprising in view of the fact that one is a scientist, the other a philosopher, and the third, a theologian.

Section 2 of this paper shows that Polkinghorne, Peacocke and Peterson approach the S-R relationship from a systematic, scientifically-oriented (type II) point of departure. Polkinghorne, for instance, is the Aristotelian ('bottom-up') thinker whose credo is 'epistemology models ontology', or, in effect, that science informs us about nature the way it 'really is.'

They are all 'critical realists,' and, as such, do not believe that postmodernism (or at least its extreme variants) has much to offer to the S-R field. Science (being conducted by humans) is, of course, socially influenced, but it is not mere intersubjective agreement or 'truth as text.'

Peacocke is the iconoclast and panentheist, who insists that religion/theology need to be radically revised, so as to become a global theology (similar to science). Peterson attempts to show that cognitive science may be relevant for the science and religion relationship.

\section{References}

Barbour, I. (1990) Religion in an age of science, San Francisco: Harper.

Bielfeldt, D (2004) Three questions about minding God, Zygon, vol. 39, no. 3.

Brown, D. (2001) Public theology, academic theology: Wentzel Van Huyssteen and the nature of theological rationality, American Journal of Theology and Philosophy, Vol. 22, Issue: 1, p95.

Cantor, G and Kenny, C. (2001) "Barbour's fourfold way: Problems with his taxonomy of science-religion relationships," Zygon, vol. 36, no. 4 , pp765 - 779 .

Clayton, P. (1989) Explanation from physics to theology: An essay in rationality and religion, New Haven: Yale University Press.

Clayton, P. (1997) God and contemporary science, Edinburgh: Edinburgh University Press.

Clayton, P. (2004) Mind and emergence: from quantum to consciousness, New York: Oxford University Press.

Crain, S. D. (1997) "Divine action and the natural sciences," Zygon, vol. 32, no. 3, p426; 432.

Drees, W. B. (1999) God and contemporary science: Philip Clayton's defense of panentheism, Zygon, vol. 34, (3), p515; 516.

Jackelen, A. (2008) An intellectually honest theology, Zygon, vol. 43, no. 1, p45; p50.

Murray, P. D. (2000) The shaping of rationality: toward interdisciplinarity in theology and science, Reviews in Religion and Theology, Vol. 7, Issue 2, p216.

Peacocke, A. (1971) Science and the Christian experiment, London: Oxford University Press.

Peacocke, A. (1999) Biology and a theology of evolution, Zygon, vol. 34, no. 4.

Peacocke, A. (2002) Paths from science towards God: the end of all our exploring, Oxford: Oneworld.

Pederson, A and Trost, L. A. (2000) John Polkinghorne and the task of addressing a 'messy world', Zygon, vol. 35, no. 4, p977; 980; 982.

Peterson, G. R. (1997) Cognitive science: what one needs to know, Zygon, vol. 32, no. 4.

Peterson, G. R. (1997a) Minds and bodies: human and divine, Zygon, vol. 32, no. 2.

Peterson, G. R. (2003) Minding God: theology and the cognitive sciences, Minneapolis: Fortress Press.

Peterson, G. R. (2008) Uniqueness, the image of God, and the problem of method: Engaging van Huyssteen, Zygon, vol. 43, no. 2, p470.

Polkinghorne, J. (1988) Science and creation: the search for understanding, Boston: Shambala.

Polkinghorne, J. (1995) Serious talk: science and religion in dialogue, Pennsylvania: Trinity Press.

Polkinghorne, J. (1996) Beyond science: the wider human context, New York: Cambridge University Press.

Polkinghorne, J (1996a) The faith of a physicist, Minneapolis: Fortress Press.

Puddefoot, J.C. (2000) God and contemporary science, International Journal of Systematic Theology, Vol. 2, (2), p228. 
Schoen, E. L. (2009) Review of 'Alone in the World'? Human uniqueness in science and theology, International Journal for the Philosophy of Religion, Vol. 65, p51.

Smedes, T. A. (2008) "Beyond Barbour or back to the basics? The future of science-and-religion and the quest for unity," Zygon, vol. 43, no. 1, p235; 255.

Stone, J. A. (2000) J. Wentzel van Huyssteen: refiguring rationality in the postmodern age, Zygon, Vol.35, (2), p424

Van Huyssteen, W, (1989) Theology and the justification of faith: Constructing theories in systematic theology, Grand Rapids, Michigan: Wm Eerdmans.

Van Huyssteen, W. (1999) The shaping of rationality: toward interdisciplinarity in theology and science, Grand Rapids, Michigan: William B. Eerdmans. 